\title{
Study on the Causes for the Large Number of Prisoners in the United States
}

\author{
Ziyue Cai \\ Jinling High School, Nanjing, China \\ Email: caiziyue2002@163.com
}

How to cite this paper: Cai, Z. Y. (2020). Study on the Causes for the Large Number of Prisoners in the United States. Open Journal of Social Sciences, 8, 278-284. https://doi.org/10.4236/jss.2020.88023

Received: July 17, 2020

Accepted: August 21, 2020

Published: August 24, 2020

Copyright $\odot 2020$ by author(s) and Scientific Research Publishing Inc. This work is licensed under the Creative Commons Attribution International License (CC BY 4.0).

http://creativecommons.org/licenses/by/4.0/

\begin{abstract}
Larger population base, the implementation of harsher laws, deep-rooted stereotypes and racist prejudices against black people mainly due to the transformation of rectification ideology, and a myriad of unsolved social problems jointly contribute to the shocking number of prisoners we see in the United States today.
\end{abstract}

\section{Keywords}

Causes, Number of Prisoners, The United States

\section{Introduction}

Due to the large scope of this question and the response word limit, this essay will focus on the reasoning behind the phenomenon of mass incarceration in the United Stated since the mid-1970s to today through the examination of natural, direct and basic causes that have gradually led to this situation.

\section{Analysis and Demonstration}

A prisoner is "a person who is kept in a prison" (Merriam-Webster Dictionary, 2017: p. 1645). Prisons in the United States are divided into two echelons: state prisons, which house prisoners who committed state crimes, also the majority of all prisoners, and federal prisons, for prisoners who committed federal crimes. Throughout the history of corrections in the United States, the mid-1970s stands as a turning point that ended almost 50 years of relatively low incarceration and witnessed a rapid and continuous influx of prisoners, disproportionally of Africa American descent. During this period of "mass incarceration" starting around 1975, the United States experienced nearly sevenfold the boost in its prison population. Compared to 240,593 prisoners in $1975,1,613,740$ were held behind bars 
in 2009 (Patrick, John, Lawrence, \& Victoria, 1988; West, Sabol, \& Greenman, 2011). Even after 2009, the prisoner population still remained high (see Figure 1). This phenomenon naturally prompts the following question: what were the causes that led to mass incarceration in the United States? In addition to the natural cause of larger population base of the United States, this essay argues that the rise in crime rate has led to the shift in the mainstream public's corrective philosophy. As a result, over the past 40 years, due to interaction between the public and politicians, stricter laws and excessive incarceration under a racially biased police system have been the most direct causes of more criminals in prison. It is worth noting that, even under harsher laws, unresolved and long-standing basic causes of social problems including economical and educational issues provided consistent criminal population base. Natural factors, direct factors and basic factors constituted the causes of mass incarceration in the United States.

The shift in the mainstream public's corrective philosophy from the emphasis on rehabilitation to punitive punishment in the 1970s, caused by rising crime rates and influential scholars at the time, provided the basis for the direct causes. Rehabilitation, a theory of punishment established in the early 19th century, is the concept that the main aim of punishment is to treat the prisoner with its "curative power" so that he/she can return to society as a law-abiding citizen (Miller, 1989). Rehabilitation theory influenced the criminal justice system and shaped policies that kept serve time relatively brief and the threshold of imprisonment relatively high, leading to low incarceration numbers. However, this mainstream theory that had dominated United States' prisons for 150 years suddenly “died" in 1975 (Cullen \& Gendreau, 1989; Miller, 1989). How did that happen? According to Latzer (2016), a former member of the Doctoral Faculty in criminal justice, starting in the 1960s, there was a period of increased number of crimes which continued into the 1980s. From 3,384,200 criminals in 1960 to $13,408,300$ criminals in 1980 , there was a $296 \%$ increment in the number of criminals. The major contributors to the crime rate increase were properties crimes and violent crimes (Disastercenter.com Editors, 2019). The crime rate clearly has a positive correlation with the size of the incarcerated population while punishment measures stay normal. Besides that, the boosting number of criminals was also a "blasting fuse" that led to the shift in mainstream correctional theory for prison.

Due to the soaring crime rate between the 1960s and the 1980s, skepticism and anxiety about the effectiveness of rehabilitation arose. Robert Martinson, a renowned criminologist, collected and screened the available reports on rehabilitation cases around the world, and conducted a survey covering 231 studies on offenders' rehabilitation (Martinson, 1974). The comprehensive evaluation of rehabilitation, published in 1975, statistically and convincingly contested that "when it came to rehabilitation, nothing worked" (Miller, 1989). This document, embraced by the already distrustful public, incurred eagerness for a substitute. The punitive punishment theory in opposition to rehabilitation emerged and was 


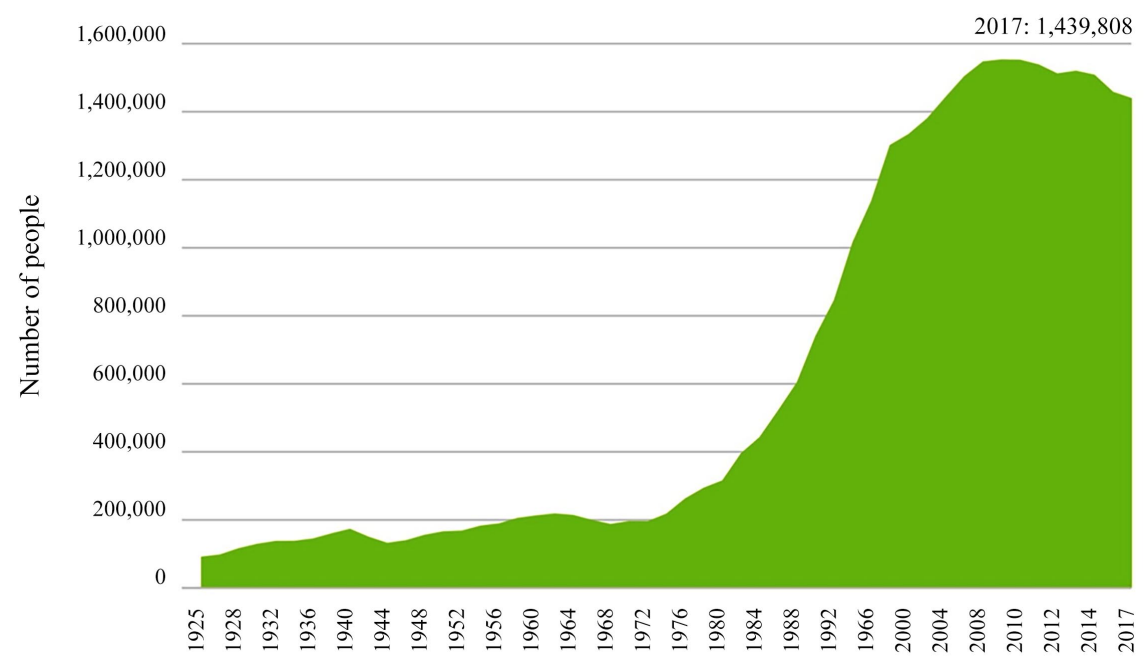

Figure 1. US State and federal prison population 1925-2017. Source: Bureau of Justice Statistics. The Sentencing Project (2018) (Due to different time of counting the number of prisoners, data in figure are slightly different from that in text).

preached to the public by another well-known political scientist James Quinn Wilson. In 1975, Wilson in his influential book Thinking about Crime argued that: if we incarcerated prisoners for a rational length of time, offenders would not disrupt the society during that period. In a more conservative tone, Wilson also acknowledged the existence and incorrigibility of "wicked people" and thus justified the necessity of separating them from "innocent people" (Wilson, 1975). Effectively, Wilson's advocation directed public opinion toward the belief that harsher laws and punishment, including increasing the length of the serve time and lowering the threshold to incarceration, were potent approaches to prevent crime. In the public sphere, slogans like "tough on crime" and "do the crime, do the time" represented the major public opinion (Travis, Western, \& Redburn, 2014). This phenomenon typified complete abolishment of rehabilitation theory and successful fulfillment of punitive punishment theory.

The increasing crime rate and the public urge for severe punishment due to punitive punishment theory induced bipartisan support of mass incarceration and harsher law enforcement, for their own career ambition, thus leading to steady increment in prisoners in the United States. Starting from Republican presidential candidate Barry Goldwater in 1964, the Republican party promoted more punitive criminal justice to create "a new majority" of Republicans by gaining public's hearts. In the election of 1968, the Republican nominee Richard Nixon became the next President, fulfilling the major political realignment (Manza \& Uggen, 2006; Alexander, 2012). Perceiving the balance shifted toward the Republicans and the steadfast public advocation for harsher policies and anti-crime campaigns, Bill Clinton and other centrist Democratic leaders decided by the late 1980s that they could not allow Republicans to be regarded as the party that was tougher on crime and thus joined the mass incarceration "team". As Democrats stepped up for harsh punishment in the 1980s and 1990s, biparti- 
san support provided unlimited fuel for the enforcement of harsh policies.

The War on Drugs campaign, for instance, started in 1971, is the most representative example of harsher policy implementation. The War on Drugs, launched by President Nixon in 1971, was aimed at cracking down on the consumption and distribution of illicit drugs. Originally only backed by Republicans, the campaign took a hiatus in the mid-1970s (History.com Editors, 2019). In the 1980s, however, after Democratic politicians joined the campaign, the harshest drug policies among all Western countries were enacted (Mosher \& Akins, 2007). Reagan fulfilled his pledge to greatly strengthen the federal government's role in fighting crime in the Anti-Drug Abuse Act of 1986 (Alexander, 2012). Federal courts, out of public view, often abused the imprisonment time under the explicit influence of politicians. In 1988, the new Anti-Drug Abuse Act authorized the five-year mandatory minimum for simple possession of cocaine, resulting in four out of five such prisoners charged with less crime like possessions, which not be likely sentenced into prisons in the past. Because of both the boosted serve time and the enlarged scope due to the lower threshold for drug prisoners, the number of drug-related prisoners skyrocketed tenfold. Drug-related crimes quickly became the greatest contributor to prison population (see Figure 2). The total number had increased 1100\% since 1980 to 2005: from 41,100 in 1980 to nearly half million people in state and federal prisons in 2005 (Mauer \& King, 2007).

Facing harsher laws supposedly applicable to all citizens of the United States, black people were unfairly targeted and made up about half of the total incarcerated population in America. Over six million African Americans migrated from the Southern to Northern America known as the Great Migration between 1910 and 1970, greatly changing the makeup of the Northern side of the country (Alexander, 2012). Equal competition between working-whites and blacks on the job market and the cost of integration discommoded the lower-and-lower-middle class white. Perceiving the public's rising unease toward the crime waves in face of black people's newly gained rights, the politicians tried to mobilize the spleen of white working-class voters to implicitly suppress the civil rights of black people. Politicians took advantage of media outlets, such as newspapers, to disseminate racist theories that the increase in crime was greatly due to black people. Broadly, as top President Nixon aide H.R. Haldeman explained, "(Nixon's implied idea) emphasized that ... the whole problem is really the blacks" and it was "us (the whites) against them (the blacks)" (Alexander, 2012). Specifically, the media reinforced the prevalent racial stereotypes of black people as "part of criminal subculture", using featured words like "crack whores" and "gangbangers" (Alexander, 2012). The intentionally racially biased will to unite white people to repress the "wicked" blacks played a significant part in causing the disproportional number of black people in prison.

The discrimination and repression of blacks was also widely observed in the War on Drugs campaign. While only $13 \%$ of all monthly drug users were black, 


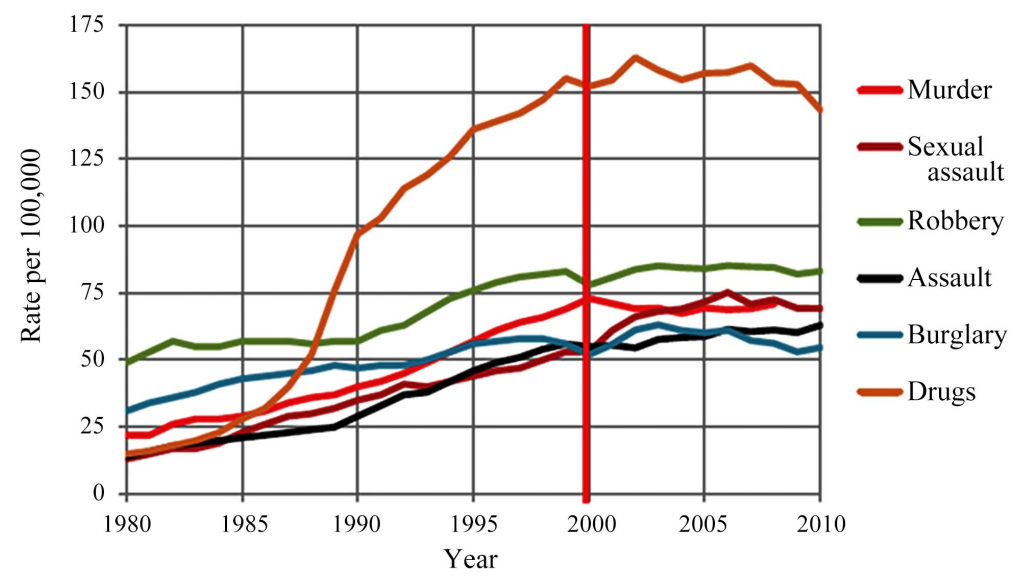

Figure 2. Combined state incarceration rate by crime type, 1980-2010.

$75 \%$ prisoners for drug possession were black (Beckett, 1997). In general, considering all prisoner types, African Americans, representing less than $6 \%$ of the general population and no more likely to commit drug crimes than whites, constituted $48 \%$ of those confined to prisons (Travis, Western, \& Redburn, 2014), (Alexander, 2012). The large exclusion of black individuals from juries forced black suspects to face all-white juries. This caused judges, who often already held prejudices against black people, to make even more partial and rigorous adjudications. Furthermore, the shutdown of methods to report for racial bias through courthouses also continued the unfair sentences. In other words, racial prejudice that led to the over-incarceration of black citizens, became one of the most important factors of the unparalleled imprisonment in the United State. Consistently built up over four presidencies, including George H. W. Bush (1989-1993) and Bill Clinton (1993-2001), this strategy effectively resulted in the steady increase of prisoners.

Even with tough laws in place, the United States has not succeeded in its original purpose of reducing criminal numbers. Although severe laws played a certain deterring role for law violation, obstinate social problems in the United States made it difficult to reduce crime. Significant economic problems and educational problems kept existing without potent mitigation strategies. With increasing wealth inequality since the 1970s, people at the bottom of the income ladder, especially those in inner-city neighborhoods, were more likely to lose their jobs and commit crimes (Saez \& Zucman, 2016). The widening wealth gap caused poor people to become ever more impoverished, with slim possibilities of upward mobility. Besides that, the high poverty rate meant that over 6.8 million children lived $50 \%$ below the poverty line in the United States. These children, having worse learning outcomes and higher high school dropout rates, were statistically more likely to commit crimes. $41.3 \%$ of US prisoners do not have a high school diploma (Harlow, 2003). The United States' incapability of mitigating intensified social problems in the past four decades caused by the widening wealth gap and imbalance of education has led to consistent criminal population despite 
harsh laws, contributing to the solid foundation and huge scope of mass incarceration.

\section{Conclusion}

Even accounting for the United States' large population, the incarcerated population of the US far outstrips all other industrialized countries, except for Russia. To conclude, the implementation of harsher laws, deep-rooted stereotypes and racist prejudices against black people mainly due to the transformation of rectification ideology, and a myriad of unsolved social problems jointly contribute to the shocking number of prisoners we see in the United States today.

\section{Conflicts of Interest}

The author declares no conflicts of interest regarding the publication of this paper.

\section{References}

Alexander, M. (2012). The New Jim Crow: Mass Incarceration in the Age of Colorblindness. New York: The New Press.

Beckett, K. (1997). Making Crime Pay: Law and Order in Contemporary American Politics. Oxford: Oxford University Press.

Cullen, F. T. \& Gendreau, P. (1989). The Effectiveness of Correctional Rehabilitation: Reconsidering the "Nothing Works" Debate. In L. Goodstein, \& D. L. Mackenzie (Eds.), The American Prison: Law, Society and Policy (pp. 23-44). Boston, MA: Springer. https://doi.org/10.1007/978-1-4684-5652-3_3

Disastercenter.com Editors (2019). United States Population and Number of Crimes 1960-2018. http://www.disastercenter.com/crime/uscrime.htm

Harlow, W. C. (2003). Education and Correctional Populations. https://www.bjs.gov/content/pub/pdf/ecp.pdf

History.com Editors (2019). War on Drugs. https://www.history.com/topics/crime/the-war-on-drugs

Latzer, B. (2016). The Rise and Fall of Violent Crime in America. New York: Encounter Books.

Manza, J., \& Uggen, C. (2006). Locked Out: Felon Disenfranchisement and American Democracy. Oxford: Oxford University Press. https://doi.org/10.1093/acprof:oso/9780195149326.001.0001

Martinson, R. (1974). What Works?-Questions and Answers about Prison Reform. The Public Interest, 42, 22-54.

Mauer, M., \& King, R. S. (2007). A 25-Year Quagmire: The War on Drugs and Its Impact on American Society. https://www.sentencingproject.org/wp-content/uploads/2016/01/A-25-Year-Quagmire -The-War-On-Drugs-and-Its-Impact-on-American-Society.pdf

Merriam-Webster Dictionary (2017). Beijing: Encyclopedia of China Publishing House.

Miller, J. (1989). The Debate on Rehabilitating Criminals: Is It True That Nothing Works? https://www.prisonpolicy.org/scans/rehab.html

Mosher, J. C., \& Akins, S. (2007). Drugs and Drug Policy: The Control of Consciousness 
Alteration. Thousand Oaks, CA: Sage Publication.

Patrick, A. L., John, V. F., Lawrence, A. G., \& Victoria, W. S. (1988). Historical Statistics on Prisoners in State and Federal Institutions, Yearend 1925-86. https://www.ncjrs.gov/pdffiles1/digitization/111098ncjrs.pdf

Saez, E., \& Zucman, G. (2016). Wealth Inequality in the United States Since 1913: Evidence from Capitalized Income Tax Data. The Quarterly Journal of Economics, 131, 519-578. https://doi.org/10.1093/qje/qjw004

Travis, J., Western, B., \& Redburn, S. (2014). The Growth of Incarceration in the United States: Exploring Causes and Consequences. Washington DC: The National Academics Press.

West, H. C., Sabol, W. J., \& Greenman, S. J. (2011). Prisoners in 2009. https://www.bjs.gov/content/pub/pdf/p09.pdf https://doi.org/10.1037/e516952009-001

Wilson, J. Q. (1975). Thinking about Crime. New York: Basic Books. 